\title{
The first Calends of the Julian Calendar
}

\author{
Amelia Carolina Sparavigna \\ Dipartimento di Scienza Applicata e Tecnologia, Politecnico di Torino, Torino, Italy
}

\begin{abstract}
This work is proposing an archaeo-astronomical study of the Julian calendar, a reform of the Roman calendar proposed by Julius Caesar. The calendar was inaugurated on the first of January, 45 BC (historical date). Using astronomical software CalSKY, we can investigate if the first day of this new system of organizing the days was corresponding to a Calenda, that is, to a day of new moon. It was on January 2, 45 BC (Julian day). We can also see how the new calendar adapted itself to the following phases of the moon.
\end{abstract}

Keywords: Archaeoastronomy, Calendars, Software.

Written 16 May 2019. DOI: 10.5281/zenodo.2860135

In origin, the Roman calendar was based on the first three phases of the moon. The days were counted, as told in [1], not according to a concept of a week, but backward from lunar phases. In this calendar, the new moon was the day of a Calenda - the Calendae, the Calends, were the first days of the months -, the first quarter was corresponding to the Nones, and the full moon to the Ides. It seems that, in origin, Calends, Nones and Ides had been linked to the first sighting of the crescent moon, the first-quarter and the full moon respectively. The Calends of each month were sacred to Juno and the Ides to Jupiter. The day before each of the above mentioned day was known as its eve (pridie) and the day after each (postridie). These days were considered particularly unlucky [2]. Like many civilizations [3], the Romans changed their lunar calendar of the origins into a calendar that better reflected the seasons. This calendar, according the tradition, was the calendar of Romulus, the founder of Rome. Around 713 BC, Numa Pompilius, the second king of Rome, reformed the calendar in order to have a better agreement between it and the seasons. Numa's calendar required days of intercalation which were determined by the Pontifices, high-ranking state priests who often held political power as well. This calendar ran for a long period of time. However, the method of adjusting the calendar based on intercalation had an intrinsic problem, and the problem was the following. Because a Roman magistrate's term of office corresponded with a calendar year, "the power of intercalation was prone to abuse: the priests could lengthen a year in order to keep an ally in office, or shorten it when an opponent was in power" [3]. This problem became particularly relevant in the years which were leading up to the Julian reform. In fact, this time was known as "the years of confusion", where the months of the calendar were no more matching the seasons [3]. Consequently, Julius Caesar decided the reform of the calendar.

The last year of confusion was $46 \mathrm{BC}$. At the time, the seasons and the calendar were three months out of alignment, so Caesar added two extra months to the year $46 \mathrm{BC}$, extending that year to 445 days. The new 365/366-day calendar was inaugurated the next year on 1 January 45 BC (709 AUC), historical date [4].The years of the reform and of the inauguration had been given by Censorinus, who tells that they were those of C. Caesar pontifex maxiumus suo III et M. Aemili Lepidi consulatu and ceteri (anni) ad nostram memoriam Iuliano appellatur, eique consurgunt ex quarto 
Caesaris consulatu (sine collega) [5].

However, we could ask ourselves what exactly was the first day of the Julian calendar as a Julian day - a manner of counting the days used in astronomy -, and also what exactly was the phase of the moon on that day. To answer we will use astronomical software such as CalSKY; Stellarium can be used too. This is an important question, as we can see from literature. For instance, we find in [6], the question formulated in the following manner: "Now in order to this inquiry [the inquiry is about the Nundinal Calendar] we must begin with assuming that the Kalendae Januariae in the first year of the Julian Aera were attached either to December 30 BC 46 or to January 1 BC 45. One or other of these assumptions we must make." The discussion given in Wikipedia, at the item en.wikipedia.org/wiki/Julian_calendar, shows that the proposal for the first Julian day of Caesar's calendar is ranging from 31 Dec 46 BC to 2 Jan 45 BC. Let us remember that the Julian day is coming from a continuous count of days since the beginning of the Julian Period (January 1, 4713 BC). Therefore, it is not a day of the Julian calendar [7]. The inventor of Julian date and Julian day was the astronomer John W. F. Herschel [7].

Now, let me propose a short discussion about the methods of counting the days in the software, such as CalSKY and Stellarium, that we can use. Let us consider year 1 BC. At the time, it was known as the Year of the Consulship of Lentulus and Piso (or year 753 Ab Urbe Condita). The denomination $1 \mathrm{BC}$ for this year has been used since the early medieval period. The following year is $1 \mathrm{AD}$ in the widely used Julian calendar, and therefore this calendar does not possess a "year zero". CalSKY has not year zero. It uses Julian dates in which year 1 BC is a leap year. In software Stellarium the year "zero" exists, so we have that 45 BC is represented as -44 . This software uses, besides the Julian date, the "astronomical year numbering", introduced in 1740 by French astronomer Jacques Cassini. Each New Year is an integer on a time axis, with year 0 corresponding to $1 \mathrm{BC}$. Year -1 is corresponding to $2 \mathrm{BC}$, and so on.

For what concerns the passage from the Julian calendar to the Gregorian calendar, this second calendar had been implemented with Julian Thursday, 4 October 1582, being followed by Gregorian Friday, 15 October 1582. In CalSKY and Stellarium 4 Oct 1582 is followed by 15 Oct 1582.

In the Table 1, we see the results that we can obtain using CalSKY, if we select to display the phases of the moon.

24 December 46 BC

\begin{tabular}{|c|l|}
\hline Time (24-hour clock) & \\
\hline 20 he8.7m & Last Quarter \\
\hline
\end{tabular}

2 January 45 BC

\begin{tabular}{|c|l|}
\hline Time (24-hour clock) & \\
\hline $1 \mathrm{~h} 35.2 \mathrm{~m}$ & New Moon \\
\hline
\end{tabular}

28 December 47 BC

\begin{tabular}{|c|l|}
\hline Time (24-hour clock) & \\
\hline $8 \mathrm{~h} 24.8 \mathrm{~m}$ & $\bigcirc$ Full Moon \\
\hline
\end{tabular}

29 December 45 BC

\begin{tabular}{|c|l|}
\hline Time (24-hour clock) & \\
\hline $4 \mathrm{~h} 46.8 \mathrm{~m}$ & D First Quarter \\
\hline
\end{tabular}

9 January 45 BC

\begin{tabular}{|c|c|}
\hline Time (24-hour clock) & \\
\hline 18 hө0.9m & D First Quarter \\
\hline
\end{tabular}

16 January 45 BC

\begin{tabular}{|c|l|}
\hline Time (24-hour clock) & \\
\hline $9440.2 \mathrm{~m}$ & $\bigcirc$ Full Moon \\
\hline
\end{tabular}

Table 1.
4 January 46 BC

\begin{tabular}{|c|l|}
\hline Time (24-hour clock) & \\
\hline $21 \mathrm{~h} 40.9 \mathrm{~m}$ & () Last Quarter \\
\hline
\end{tabular}

5 January 44 BC

\begin{tabular}{|c|l|}
\hline Time (24-hour clock) & \\
\hline $1 \mathrm{~h} 13.6 \mathrm{~m}$ & $\bigcirc$ Full Moon \\
\hline
\end{tabular}

Table 2. 
We can see that January 2, 45 BC was marked as a day of new moon. This fact is fixing the year (45 BC) for sure. Actually, the year before, on 28 December 47 BC, we had the full moon, and therefore year 46 BC started between the full moon and the last quarter (Table 2, upper line). The following year (44 BC) started with the moon between the first quarter and the full moon (Table 2, lower line).

In the Figure 1, it is shown the simulation obtained by means of Stellarium. We can also see that, at the time, the sunrise was announced by Saturn and Jupiter. On January 1, -44, the moon was waning. On January 2, -44, it was waxing. Therefore, new moon was on January 2.
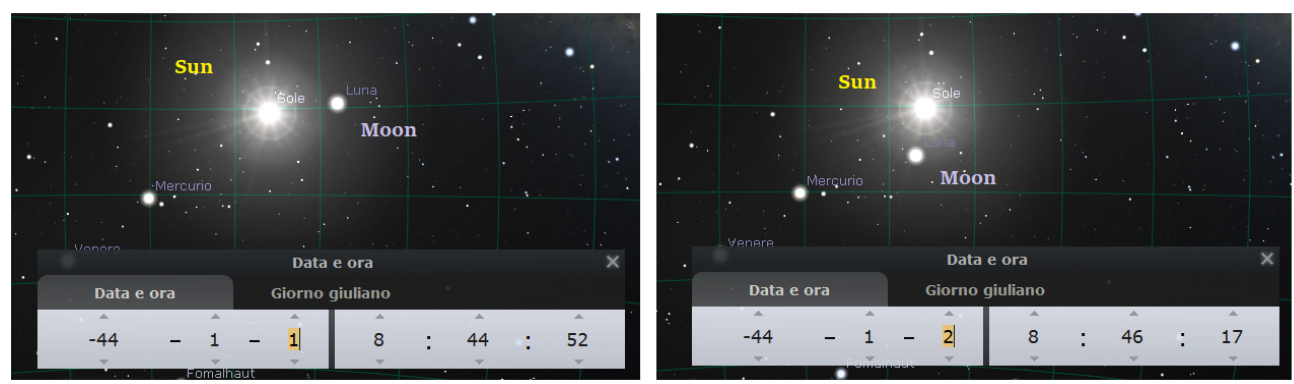

Figure 1: Simulation by means of Stellarium.

From the Table 1, we have that the new moon was in the night between the first of January and January 2. In the software, it is given at $1 \mathrm{~h} 35 \mathrm{~m}$ of Jan 2 . Therefore it was facing the other side of the globe. In any case, close to the new moon, the lunar disk is not visible to the unaided eye, because the daylight outshines the earthlight that dimly illuminates the new moon. So, on Jan 1 and Jan 2 of 45 BC the moon was not visible. However, for the ancient astronomers, who were working for Caesar, it was quite easy to estimate the phase of the new moon, by observing its behaviour in the preceding days (Table 3, set location Rome). In the Table 3 we can see in detail the moon from Dec 29, 46 BC, and Jan 19, 45 BC. As in the case of the Calends, the full moon (Ides) are between Jan 15 and Jan 16.

\begin{tabular}{|c|c|}
\hline $29 \mathrm{Dec} 46 \mathrm{BC}$ & $11.7 \%$ waning. \\
\hline $30 \mathrm{Dec} 46 \mathrm{BC}$ & $6.2 \%$ waning. \\
\hline $31 \mathrm{Dec} 46 \mathrm{BC}$ & $2.4 \%$ waning. \\
\hline 1 Jan $45 B C$ & $0.4 \%$ waning. \\
\hline 2 Jan $45 B C$ & $0.3 \%$ waxing \\
\hline 3 Jan $45 B C$ & $2.2 \%$ waxing \\
\hline 4 Jan $45 B C$ & $6.2 \%$ waxing. \\
\hline 5 Jan $45 B C$ & $12.0 \%$ waxing. \\
\hline 6 Jan $45 B C$ & $19.6 \%$ waxing. \\
\hline $7 \mathrm{Jan} 45 \mathrm{BC}$ & $28.7 \%$ waxing. \\
\hline $8 \mathrm{Jan} 45 \mathrm{BC}$ & $.0 \%$ waxing \\
\hline
\end{tabular}

\begin{tabular}{|c|c|}
\hline 9 Jan 45BC & $50.2 \%$ waxing. \\
\hline 10 Jan 45BC & $61.6 \%$ waxing. \\
\hline 11 Jan 45BC & $72.7 \%$ waxing. \\
\hline 12 Jan 45BC & $82.8 \%$ waxing. \\
\hline 13 Jan 45BC & $91.1 \%$ waxing. \\
\hline 14 Jan $45 B C$ & $96.9 \%$ waxing. \\
\hline 15 Jan $45 B C$ & $99.6 \%$ waxing: \\
\hline 16 Jan $45 B C$ & $99.7 \%$ waxing. \\
\hline 17 Jan 45BC & $99.3 \%$ waning. \\
\hline 18 Jan $45 B C$ & $95.9 \%$ waning. \\
\hline 19 Jan $45 B C$ & $90.1 \%$ waning. \\
\hline
\end{tabular}

Table 3. 
So, using CalSKY, and assuming that the new calendar started on a Calenda, the first astronomical date of the Julian Calendar was January 2, 45 BC. Starting from January 2, the full moon (January 16) was after fifteen days (in an inclusive counting). As we will see in the following, the astronomical day of January 2 is also a good choice to have a good agreement to old calendars based on the moon. So the historical January 1, 45 BC could have be the Julian day January 2.

The proposal of January 2 is not a new proposal, as we have seen before. Let me report a discussion given in [8] by Henry Browne, entitled The Nundines, and early times of the Julian Calendar. This discussion is important because it explains how the Julian Calendar was applied, and the leap years used, until its reform operated by Augustus in 8 AD.

"The reformed calendar started on its course on the 1st of January B.C. 45. If, as is usually supposed, its first year was bissextile, the subsequent bissextile years should have been 41, 37, 33, \&c.; but on the supposition, which is equally probable, that it was meant to begin with three common years followed by a bissextile year, the leap-years should have been B.C. 42, 38, 34 \&c. Which of these was prescribed by the rule, we cannot say, Caesar's edict unfortunately being lost. The rule itself, however, was transgressed from the first: the ignorant pontifices, understanding quarto quoque anno to mean a period of three years complete, intercalated the years 42, 39, 36, 33 \&c. to B.C. 9 inclusive, when the error being discovered was rectified, and the Julian notation of time restored to its proper track, by omitting the bissextile day of B.C. 5, 1 and A.D. 4, i.e. of the 41st, 45th, and 49th Julian years. Now, since a period of three years including one bissextile contains 1096 days, which number is divisible by 8 without remainder, it follows, that so long as the erroneous intercalation lasted, the nundines would constantly fall on the same days at intervals of three years."

The text continues with a discussion on nundines. After, we find the following.

"There is a further circumstance, of an astronomical nature, which points to the same conclusion. There is reason to believe that the inducement for giving to U. C. 708 ("the year of confusion") the precise length of 445 days was, that the beginning of the new reckoning should be the day of new moon next after the winter solstice. Now the date of that new moon, in our technical and proleptic application of the Julian reckoning (i.e. in the uninterrupted continuation, upwards, of the Julian calendar, old style) is, about an hour and a half after midnight between 1 and 2 Jan. B.C. 45 . But the day which we, in this reckoning, call 2 Jan. was by the Romans then living called 1 Jan., if the year was not actually bissextile. On this supposition, Caesar's 1st of January of the new calendar did actually begin with the day and almost the precise hour of the new moon; and thus we may understand the meaning which lies under the vague statement of Macrobius: Annum civilem Caesar habitis ad lunam dimensionibus constitutum edicto palam proposito publicavit. In short, the day which Caesar chose to be the first of the new reckoning was at once the first day of the Roman eight-day week [nundines] and of the lunar month. For comparison with the Egyptian calendar it possessed the further advantage of being the first day of Tybi (the $5^{\text {th }}$ month), viz. of the year of Nabonassar 703.

We may also fairly urge, with Sanclemente [Enrico Sanclemente], that the beginning of the new reckoning with a bissextile year is in itself improbable; the common years would naturally take precedence: though when this writer supposes that there was no intercalation until the Feb. of B.C. 41 , this violates, at the very outset, the principle of the reckoning, which is, that every four successive years, wherever taken, should constantly number 1461 days. The most natural supposition is, that the first three years of the reckoning were common years, and the fourth 
bissextile: this we know was the rule of the Julianized Egyptian calendar, beginning at the 1 Thoth of B.C. 30, viz. three years of the ordinary length, and the fourth a year of 366 days, i. e. with a sixth epagomené at the end. In fact, Sanclemente, in common with other writers on the calendar, seems to have assumed that by the edict of Augustus the order of the Julian intercalation was restored in conformity with the intention of its author: i.e. that as, since the restoration, the bissextile year is the $4 \mathrm{~m}+1$ st Julian year, it was always intended to hold that place. I do not see that this is the necessary inference. The years marked for intercalation by the pontifices were the 4th, 7th, 10th, \&c., and thus went on till the 37th = B.C. 9: Augustus may have made this last year the starting point for future intercalations; or, independently of this, the year of his edict, B.C. 8, was made the first year of the quadriennial periods, only with the understanding that the first three bissextile days should be omitted. I suppose then that it was in conformity with Caesar's rule that the pontifices intercalated the year 42 B.C. being the fourth Julian year. Then in their ignorance which, Julius Caesar being dead, there was none to control, they held that as the first bissextus was ordered to be inserted when the calendar had been only three years in existence, the next must be three years later (quarto quoque anno in the more usual sense of the phrase), and so on perpetually. ... If this be the true history of the earlier years of the Julian reckoning, it follows, that historical Roman dates derived from contemporary records between 1 Jan. B.C. 45 and 1 Mar. A.D. 4, will vary more or less from the technical dates obtained by continuing the calendar upwards without interruption from the latter date, at which, in any case, the proleptic Julian reckoning must be understood to begin. Ideler [Christian Ludwig Ideler], [Handb, der Chron.] II, p. 133, has marked the rules of this divergence, as it results from the usual account, in which the actually intercalated years are said to have been B.C. 45, 42, 39 \&c. to B.C. 9 inclusive. On the view here put forward, the rule must be modified as follows:

From (historical) 1 Jan. 45 to 28 Feb. of same year add 1.

From ......... 29 Feb. $42 *$ to 28 Feb. 41 add 1.

From ........ 29 Feb. $40 *$ to 28 Feb. 34* add 1.

From ......... 29 Feb. 34* to 28 Feb. 33 add 2.

From ......... 28 Feb. 33 to 28 Feb. 31* add 1.

From ......... 29 Feb. $31 *$ to 27 Feb. 29 add 2.

From ......... 28 Feb. 29 to 28 Feb. 28* add 1.

From ........ 29 Feb. 28* to 28 Feb. 22* add 2.

From ......... 29 Feb. 22* to 28 Feb. 21 add 3.

From ......... 1 Mar. 21 to 28 Feb. 19* add 2.

From ......... 29 Feb. 19* to 28 Feb. 17 add 3.

From ......... 1 Mar. 17 to 28 Feb. 16* add 2.

From ......... 29 Feb. 16* to 28 Feb. $10^{*}$ add 3.

From ......... 29 Feb. $10 *$ to 28 Feb. 9 add 4.

From ......... 1 Mar. 9 to 28 Feb. 5 add 3.

From ......... 1 Mar. 5 to 28 Feb. 1 add 2.

From ......... 1 Mar. 1 to 28 Feb. A.D. 4 add 1.

The years marked * are the actual, the others the proleptic bissextiles.

For example, the battle of Actium was fought, according to Dio Cassius, on the 2nd September U. C. 723 = B. C. 31. The corresponding proleptic Julian date is 4 Sept.; on the usual view (Ideler's), 3 Sept. Again, there was an eclipse of the sun in B. C. 10 for which the astronomers give the proleptic 
Julian date 30th June. Should any contemporary record with the Julian date hereafter be discovered, it should on my view be the 26th June, on Ideler's the 27th.”

In the Figure 2, Stellarium simulates the eclipse mentioned by Henry Browne.

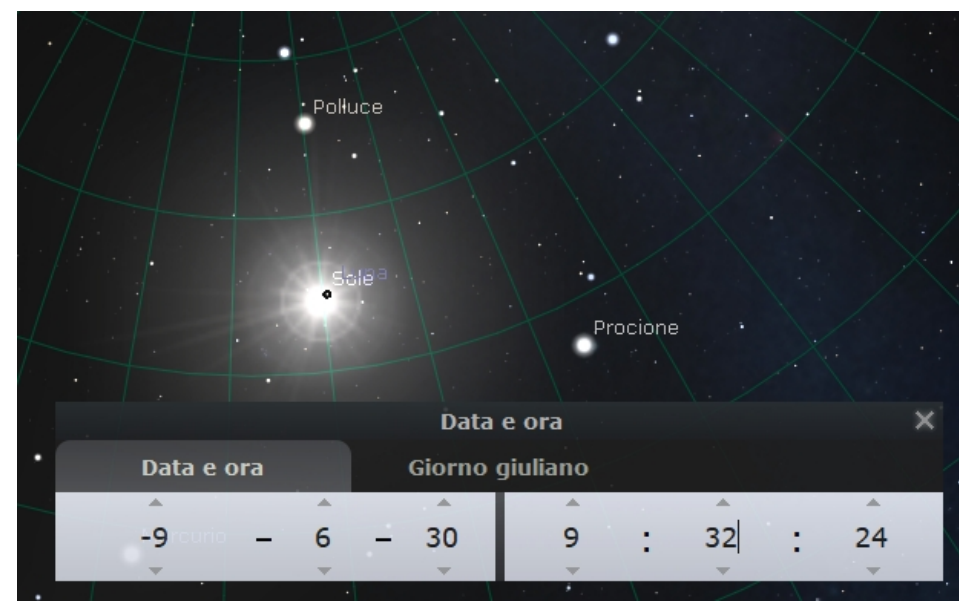

Figure 2.

According to CalSKY, we have

$$
\begin{array}{|l|l|}
\hline 30 \text { Jun } 10 & \text { Rise: } 4 \text { he5m }\left(a z=57^{\circ}\right) \\
\hline \text { Transit: } 11 \mathrm{~h} 59 \mathrm{~m}\left(\mathrm{~h}=72.3^{\circ}, \mathrm{k}=0.0 \% \text { waning, } \mathrm{Cnc}, \text { colon }=272^{\circ}\right)
\end{array}
$$

If we consider Browne's observations, we have to be very careful when we consider the dates given in historical references, and when we want to compare them to the astronomical reckoning.

A discussion in the note of Browne's text is also very interesting.

"Nature prescribes no "true time" for the beginning of the solar year: how the days of the year shall be numbered and named is simply matter of conventional arrangement. In the year of Numa and the Decemvirs it was doubtless intended that the Calends of April and October, of July and January, should never travel very far from the cardinal points of the sun's annual course, the equinoxes and the solstices. The point for consideration with Caesar and Sosigenes was, to which of the 365+1/4 days which they assumed to be a sufficiently exact measure of the interval between two successive vernal equinoxes \&c., they should assign the name Calends of January. Conceiving Hipparchus's determination to be still in force, they held that the bruma of U.C. 708 fell on the 23rd of Choeak of the Egyptian year (AE. Nab. 703): they might have set their 1st of January at that day; they chose to set it eight days later. By the combination in the text it has been attempted to explain the grounds of their choice, and the result is this. For the more convenient adjustment of the lunar cycle and its epacts, they chose for the beginning of the new year the day of new moon next after the bruma, which day possessed the farther twofold advantage of being the 1st day of the Roman nundine week, and also the 1st of the Egyptian month Tybi with which begins the second of the three seasons or quaternions of months into which the Egyptian year is divided. The advantages, in a technical point of view, of these coincidences were not to be overlooked. Caesar, we know, had studied astronomy under Egyptian masters: siderum motus, de quibus non indoctos libros reliquit, ab Aegyptiis disciplinis hausit, Macrob. Saturn. I. 16.” 


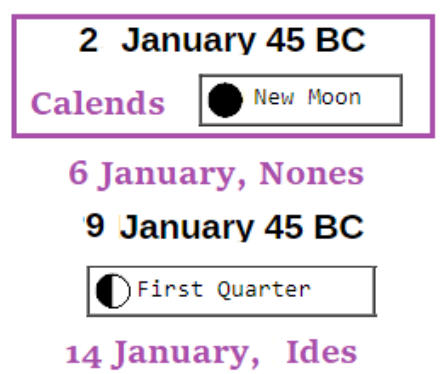

16 January 45 BC

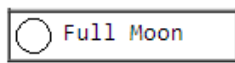

1 February 45 BC

New Moon

2 February, Calends

6 February, Nones

7 February 45 BC

Dirst Quarter

14 February, Ides

15 February 45 BC

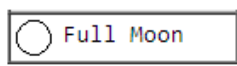

1 March 45 BC

New Moon
2 March, Calends

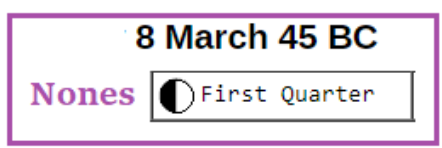

15 March 45 BC

Full Moon

16 March, Ides

31 March 45 BC

New Moon

2 April, Caldens

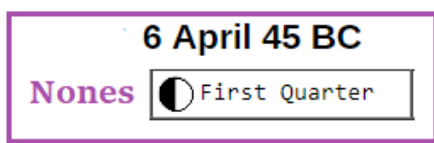

\begin{tabular}{|l|}
\hline 14 April 45 BC \\
Ides $\bigcirc$ Full Moon
\end{tabular}

29 April 45 BC

ONew Moon

2 May, Calends

Table 4.

Let us also stress, using CalSKY and the Table 4, some coincidences that we can have, starting from Jan. 2 of 45 BC, with the phases of the moon (location Rome). Actually, for what concerns the counting of the days, the Julian reform did not change the method used to account days of the month in the pre-Julian calendar, based on the Calends, Nones and Ides (see Appendix). From Table 4, we have coincidences for the Ides of April and the Nones of March and April. Not that on March 2, the moon was at $1.7 \%$. The Ides of February and March differ of a day, like the Calends.

After the previous discussion and, in particular, according to Henry Browne's discussion, sentences as that we find in [9] for instance, are fake and misleading. "It was probably the original intention of Caesar to commence the year with the shortest day. The winter solstice at Rome, in the year 46 B.C., occurred on the 24th of December of the Julian calendar. His motive for delaying the commencement for seven days longer, instead of taking the following day, was probably the desire to gratify the superstition of the Romans, by causing the first year of the reformed calendar to fall on the day of the new moon." As we have seen before, it was not the desire to gratify the superstition of the Romans the reason for starting the calendar from the first new moon of January. From literature, the Julian days proposed for the historical January 1, 45 BC are Jan. 1 and Jan. 2. Browne opted for January 2. In my opinion, this is the proper day because, as we can see from Table 4, the new calendar could have been in good agreement to the traditional Roman calendar, during the first part of the year. For this reason, it was more easy for people to manage it, in the first period of its use. 


\section{References}

[1] https://www.thoughtco.com/roman-calendar-terminology-111519

[2] https://en.wikipedia.org/wiki/Roman_calendar

[3] Robert Coolman, Keeping Time: Months and the Modern kalendars, Live Science. May 15, 2014 https://www.livescience.com/45650-calendar-history.html

[4] Handy-book of Rules and Tables for Verifying Dates of Historical Events, and of Public and Private Documents: Giving Tables of Regnal Years of English Sovereigns ... 1066-1866. John James Bond. Bell and Daldy, 1866

[5] Gianpaolo Urso, L'ultimo Cesare: scritti, riforme, progetti, congiure : atti del convegno internazionale, Cividale del Friuli, 16-18 settembre 1999. L'ERMA di BRETSCHNEIDER, 2000 [6] Origines Kalendariae Italicae Nundinal Calendars of Ancient Italy, Nundinal of Calendar of Romulus, Calendar of Numa Pompilius, Calendar of the Decemvirs, Irregular Roman Calendar, and Julian Correctio Tables of the Roman Calendar, from V. C. 4 of Varro, B. C. 750, to V. C. 1108 A. D 355. 4 by Edward Greswell, B.D: Vol. 4, Volume 4. Pag.104, University Press, 1854.

[7] Peter Meyer. Julian Day Numbers. www.hermetic.ch/cal_stud/jdn.htm\#julian_day_number [8] Henry Browne, The Nundines, and early times of the Julian Calendar.THE JOURNAL OF CLASSICAL AND SACRED PHILOLOGY, VOL. III., Cambridge, 1857.

[9] Calendarium. The Roman section only of an article by Thomas Hewitt Key, M.A., Professor of Comparative Grammar in University College, London, on pp.222-233 of William Smith, D.C.L., LL.D.: A Dictionary of Greek and Roman Antiquities, John Murray, London, 1875.

http://penelope.uchicago.edu/Thayer/E/Roman/Texts/secondary/SMIGRA*/Calendarium.html [10] Syntax of the Latin Language: Chiefly from the German of C. G. Zumpt. Charles Beck J. Munroe, 1844. Pag.177. 


\section{Appendix}

Let us show the manner that the Romans used for counting the days. The method is given in the following Figure from Ref.10.

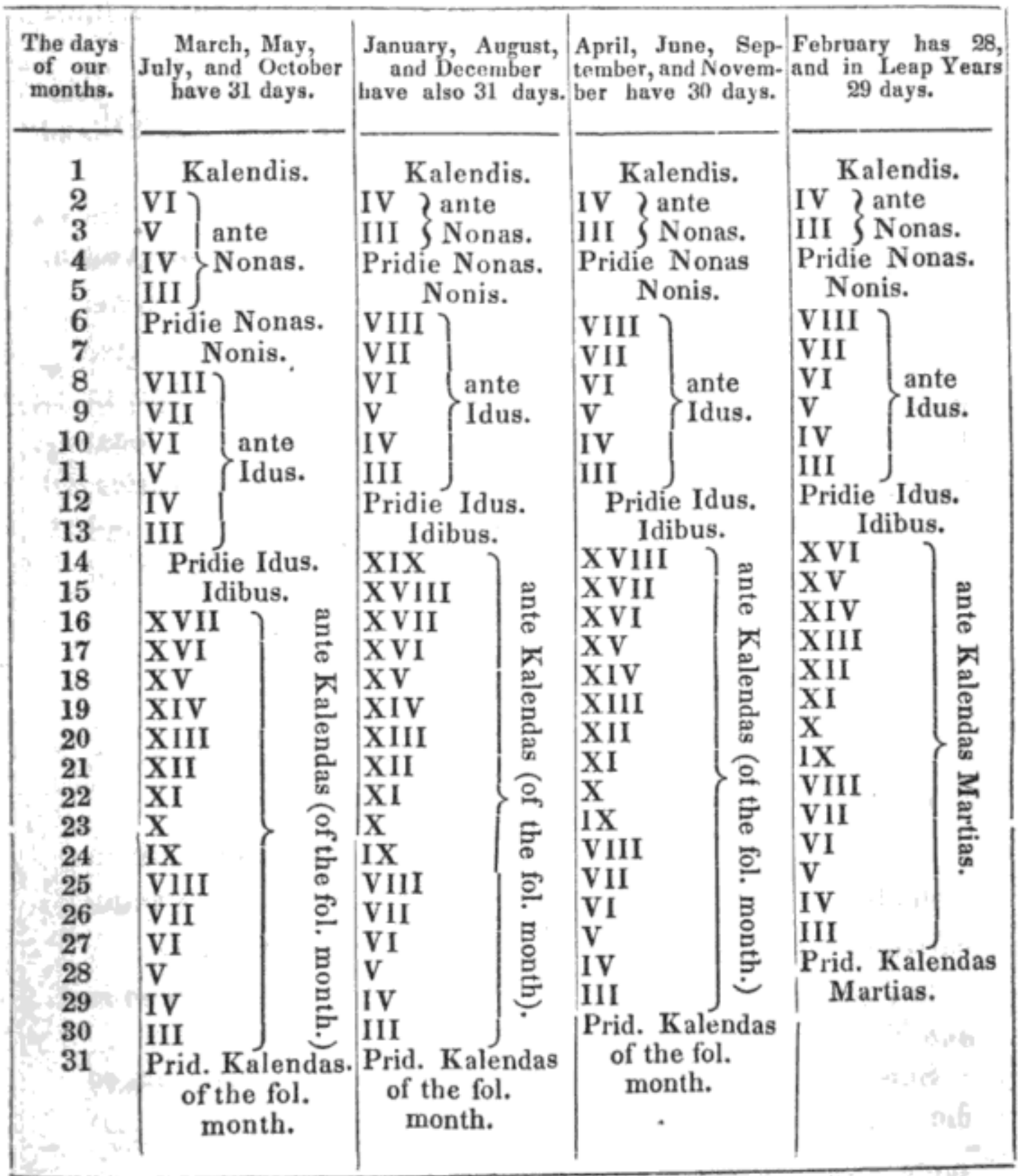

For what concerns the counting of the days, Ref.10 is telling that "The mode of denoting the days of the month will cause no difficulty, if it be recollected, that the kalends always denote the first of the month, that the nones occur on the seventh of the four months March, May, Quinctilis or July, and October, and on the fifth of the other months; that the ides always fall eight days later than the nones; and lastly, that the intermediate days are in all cases reckoned backwards upon the Roman principle already explained of counting both extremes.” The Julian reform did not change the method used to account days of the month in the pre-Julian calendar, based on the Kalends, Nones and Ides. 